\title{
Engeberg, A. (2020). Walking on the pages of the Word of God: self, land, and text among Evangelical volunteers in Jerusalem. Leiden/Boston: Brill. 213 p.
}

\section{LEONARDO MARCONDES ALVES}

VID SPECLALIZED UNIVERSITY, STAVANGER, NORUEGA

HTTP://ORCID.ORG/OOOO-0002-7I68-4222

Fruto do projeto de doutorado em Cristianismo Global e Relações Inter-religiosas (2016), executado através do Centre for Theology and Religious Studies da Universidade de Lund, Suécia, o livro de Aron Engeberg combina pesquisa empírica com uma análise teológica, inserindo-se na tradição nórdica de pesquisas empíricas nos campos de teologia e ciências da religião. Os dados etnográficos são oriundos de três anos de trabalho de campo, de setembro de 2011 a maio de 2013, entre voluntários de três organizações cristãs sionistas em Jerusalém: International Christian Embassy, Bridges for Peace e Christian Friends of Israel. Engeberg realizou entrevistas com voluntários e líderes, frequentou eventos e círculos sociais dessas comunidades e complementou sua pesquisa com investigações em arquivos locais.

Walking on the pages of the Word of God contribui significativamente em várias áreas, tais como a antropologia do cristianismo, o debate Israel-Palestina, as relações internacionais por atores transnacionais, a tendência recente de estudos empíricos sobre hermenêutica e a antropologia da leitura. $\mathrm{O}$ livro revolve em torno dos motivos pelos quais voluntários cristãos de diversos países do mundo se dedicam a prestar serviço em organizações evangélicas sionistas em Jerusalém. Sob essa linha condutora, o autor retrata com nuances as posições sionistas cristãs evangélicas nos discursos teológicos a respeito de Israel e da Palestina, entendida como a expressão de um conflito sobre o significado religioso. Neste retrato, os sujeitos articulam como as palavras, os objetos materiais e os eventos históricos significam (ou não) uma intencionalidade divina.

Em seis capítulos o autor argumenta que no cerne da motivação para os voluntários se deslocarem e passarem um tempo nessas organizações está uma hermenêutica específica. O modo de ler a Bíblia, sua aplicabilidade aos eventos contemporâneos e as maneiras pelas quais Deus age sobre e por meio do mundo material pressupõem a fundação do Estado de Israel como um "sinal dos tempos", um evento de redenção divina. Esta hermenêutica não se restringe somente ao texto sagrado, mas se aplica de modo similar ao próprio espaço, dado o caráter histórico e escatológico das terras do Levante. Adicionalmente, este modo de interpretação enquadra as próprias histórias de vida dos voluntários e os 
eventos no mundo. Assim, o conflito é religioso, pois não se refere ao choque de ideologias nacionais ou contestações sobre a terra, mas ao plano de Deus para a redenção do mundo.

Nessa obra, o conceito operacional de sionismo cristão expressa uma tradição narrativa transmitida socioculturalmente preocupada com a conexão entre o Israel contemporâneo, sua ideologia formativa e a concepção cristã de história sagrada. As três organizações pesquisadas funcionam como ONGs, atuando tanto em serviços sociais à população quanto fazendo um lobby público pelo Estado de Israel. Seus integrantes são oriundos principalmente dos Estados Unidos e, recentemente e de modo crescente, de outras nações do Sul Global, provenientes de igrejas evangélicas (Evangelicals no senso anglo-saxão), fundamentalistas, pentecostais e carismáticas. No entanto, o autor salienta a oposição à teologia e às ideologias dessas organizações por outras denominações evangélicas, pentecostais e liberais que subscrevem a outras posturas políticas ou teológicas.

No capítulo introdutório, Engeberg apresenta a investigação e discute as dificuldades de se escolher este tópico, dentre elas a relação tensa entre a academia e a pesquisa com grupos religiosos conservadores. A questão central é como pessoas com praticamente nenhuma relação ou conhecimento do Estado de Israel se identificam com ele de tal modo para se voluntariar ao trabalho nas organizações cristãs sionistas. O capítulo seguinte, "Evangelical Zionism in Jerusalem”, oferece um panorama histórico e das posturas políticas do sionismo evangélico em Jerusalém, indicando como essas organizações, à época da pesquisa, evitavam discutir as políticas internas do Estado de Israel bem como se esforçavam para manter uma imagem positiva nas relações públicas com a mídia israelense.

As histórias de vida, incluindo as da vinda para Israel, envolvem os meios de agência e autotransformação. Tema central do terceiro capítulo, "Self: Calling, Agency, and Transformation”, essas narrativas, similares às histórias de conversão, integram um público heterogêneo, mas unidos pelas experiências religiosas e hermenêutica do sagrado. Já no quarto capítulo, "Land: Israel, Place, and Presence", Engeberg passa à discussão sobre a terra. As relações entre Israel, o lugar e a presença são apresentadas sob a produção narrativa dos voluntários como um "espaço sagrado", com uma capacidade única de mediar a presença divina. Nessas narrativas, é recorrente o tema da "volta para a casa".

O quinto capítulo, “Text: Literalism, Prophecy, and Authenticity”, concentra as análises sobre a tradição interpretativa dos voluntários. A partir de uma ideologia do literalismo na interpretação da Bíblia, esta tradição interpretativa providencia um arcabouço para compreensão do mundo. Os sionistas evangélicos creditam a influência do helenismo como a causa subjacente do fracasso cristão em reconhecer a fundação do moderno Israel como um sinal dos tempos. Argumentam que leem a Bíblia "literalmente" (pressuposto contestado pela literatura antropológica com a qual o autor dialoga) para considerar as profecias, ambíguas que sejam, como guia para interpretar eventos históricos, experiências contemporâneas, expectativas e desejos futuros. Para os sujeitos da pesquisa, os significados teológicos de Israel não dependem exatamente de leituras literais de profecias bíblicas, mas também do papel simbólico de Israel como autenticador das práticas particulares de leitura entre os evangélicos.

No capítulo final, de título homônimo ao livro, os três aspectos - self, terra e texto - são integrados para explicar como a partir dessas categorias uma relação espiritual significante emerge. Nesse capítulo, o autor registra o relativo isolamento dos voluntários nas comunidades evangélicas sionistas. 
Reporta o pouco contato dos voluntários com israelenses de outras identidades, tampouco com os palestinos. Isso explica, para o autor, algumas lacunas sobre o conflito palestino-israelense nas narrativas sagradas dos voluntários, enquanto as lideranças objetam às políticas de cessão de terras para a paz ou a solução dos dois estados. Todavia, o entendimento que os voluntários possuem da questão da Palestina como conflito espiritual seria uma área que o autor poderia ter aprofundado. $\mathrm{O}$ autor instiga novas pesquisas sob o ponto de vista dos voluntários cristãos que trabalham em círculos palestinos.

Talvez uma das maiores contribuições que o autor faz é proporcionar um retrato para entender os componentes ideológicos de grande parte de segmentos evangélicos e pentecostais. Embora seja um estudo situado em um espaço, tempo e filiações religiosas específicas, as análises têm o potencial de serem aplicada para a compreensão do comportamento político evangélico contemporâneo em diversas partes do mundo, inclusive na América Latina. A perspectiva de tratar fenômenos religiosos em seus próprios termos, não como variáveis de outros fatores - quer econômicos, quer políticos - foi realizada com maestria.

A obra, disponível gratuitamente em formato digital e em acesso aberto (em: http://library. oapen.org/handle/20.500.12657/38114) além de sua edição impressa, é indicada para informar os debates sobre os conflitos geopolíticos do Oriente Médio. Adicionalmente, serve como uma introdução atualizada aos seus campos e áreas mencionados, especialmente nos cursos de pós-graduação em humanidades e nas ciências sociais.

Leonardo Marcondes Alves é mestre em Antropologia pela Universidade de Uppsala, Suécia, doutorando em Ciências da Religião e pesquisador (Research Fellow) na VID Specialized University, Stavanger, Noruega.

RECEBIDO: $26 / 01 / 2021$

ACEITO: 08/09/2021 